\title{
Antibiotic Resistance of $E$. Coli lsolates from Broiler Chick's Cecum in Makassar City
}

\author{
Erdi Purwanto ${ }^{1 *}$, Dini Marmansari', Dwi Kesuma Sari², Muhammad Hatta ${ }^{3}$ \\ 'Maros Veterinary Centre, Jl. Dr. Ratulangi, Allepolea, Lau, Maros District, 90514, South Sulawesi, \\ Indonesia \\ 2Study Program of Veterinary Medicine, Faculty of Medicine, Hasanuddin University, Jl. Perintis \\ Kemerdekaan Km. 10, Makassar, 90245, South Sulawesi, Indonesia \\ ${ }^{3}$ Department of Microbiology, Faculty of Medicine, Hasanuddin University, Jl. Perintis Kemerdekaan
}

Km. 10, Makassar, 90245, South Sulawesi, Indonesia

Corresponding author: erdibbvet@gmail.com

\begin{abstract}
Broiler chickens or broilers are the cheapest sources of animal protein that can be obtained apart from eggs. The high demand for broiler chicken meat is fulfilled because modern broilers grow rapidly and are maintained massively and intensively. Massive maintenance systems make the spread of disease easier. Treatment of bacterial diseases using inappropriate antibiotics can lead to antibiotic resistance. This study aims to look at the antibiotic resistance of Escherichia coli (E. coli) bacteria from broiler chickens. $E$ coli bacteria were isolated from 34 samples of broiler chicken cecum taken from several large traders in the city of Makassar. The E. coli isolates were then tested using Kirby-Bauer's diffuse disc method on 5 types of antibiotics from 5 classes of antibiotics namely: Ampicillin ( $\beta$-lactam); Tetracycline (Tetracycline); Gentamicin (Aminoglycosides); Enrofloxacin (Fluoroquinolone); Sulfamethoxazole-Trimethoprim (Sulfonamide). The inhibition zone formed was interpreted using the CLSI 2018 standard. The results of this study were $79.4 \%$ of the samples resistant to Ampicillin, $85.3 \%$ resistant to Tetracycline, $61.8 \%$ resistant to Sulfamethoxazole-Trimethoprim, $76.5 \%$ resistant to Enrofloxacin and $52.9 \%$ were resistant to Gentamicin. With $91.18 \%$ of the sample being resistant to at least 2 types of antibiotics.
\end{abstract}

Key words: antibiotic resistance, E.coli, chicken, broiler, Makassar

Copyright $\odot 2019$ JRVI. All rights reserved.

\section{Introduction}

The problem of antibiotic resistance is a problem that comes along with the discovery of antibiotics. Bacteria develop their ability to withstand antibiotic exposure. The use of antibiotics that are not the right type, dose and duration of use accelerates this resistance. Resistant bacteria can transfer their resistance ability to other bacteria. One way is to exchange genetic information through plasmids.

The administration of antibiotics in poultry is generally carried out through drinking water so that the intestinal microflora becomes the most frequently exposed microbes. As one of the normal intestinal microflora, $E$. coli is often used as an object of study both used as a sign of contamination as well as to see the ability of antibiotic resistance. Another characteristic of $E$. 
coli is that it easily spreads its resistance to other bacteria through plasmid exchange. The incidence of antibiotic resistance in humans is due to irrational use of antibiotics in humans themselves, as well as contamination of consumed animal products and environmental contamination from animals that also have antibiotic-resistant microbes (Siswanto, 2014). To see an overview of $E$. coli antibiotic resistance in the intestine, sampling is done in the caecum, this is also to avoid contamination of E.coli from the environment.

\section{Materials and Methods}

Sampling was carried out at the Poultry Slaughterhouse (PSH) in Makassar City. Broiler chickens cut in PSH can come from several cages in several regions around Makassar City, such as Gowa, Maros and Takalar, also Sidrap and Pinrang Regencies. The equipment used for sampling is tweezers, scissors, and sterile zip plastic, labels, icepack, and coolbox. Tests are carried out at the Veterinary Public Health Laboratory, Maros Veterinary Center. The cecum is opened; the contents/feces are taken using an ose then scratched in Levine Eosin Blue Methylene (L-EMB) Agar, incubated at $35^{\circ} \mathrm{C}$ for $18-24$ hours. Colonies measuring $2-3 \mathrm{~mm}$, dark nuclei, with or without metallic green luminescence are thought to be $\mathrm{E}$. coli colonies. The colonies were taken and then streaked into Nutrient Agar (NA) for resistance testing and Plate Count Agar (PCA) for biochemical tests. For biochemical confirmation refers to the Indonesian National Standard (SNI) 2897 of 2008 concerning Testing Methods for Microbial Contaminations in Meat, Eggs and Milk and Processed Products. If confirmed E. coli, then taken one ose from NA, made a suspension with physiological $\mathrm{NaCl}$, equated turbidity with $0.5 \mathrm{McF}$ arland. Sterile cotton swabs are used to pick up the suspension so that the cotton is not too wet by pressing the cotton on the edge of the suspension bottle. Swabs are spread on Mueller-Hinton media evenly 3 times. Every time the scratch, petri is turned $60^{\circ}$ so that the media is completely closed. Wait 5-10 minutes so that the suspension dries, stick the disc containing antibiotics, incubate $35^{\circ} \mathrm{C}$ for 18 24 hours. The inhibitory zone results are then interpreted using the $2018 \mathrm{Clinical}$ and Laboratory Standards Institute (CLSI) standard.

\section{Results}

Results from the inhibitory zone of 34 samples at Mueller Hinton were interpreted using the CLSI 2018 standard. Only one sample showed no antibiotic resistance, while the other showed antibiotic resistance with the following percentage.

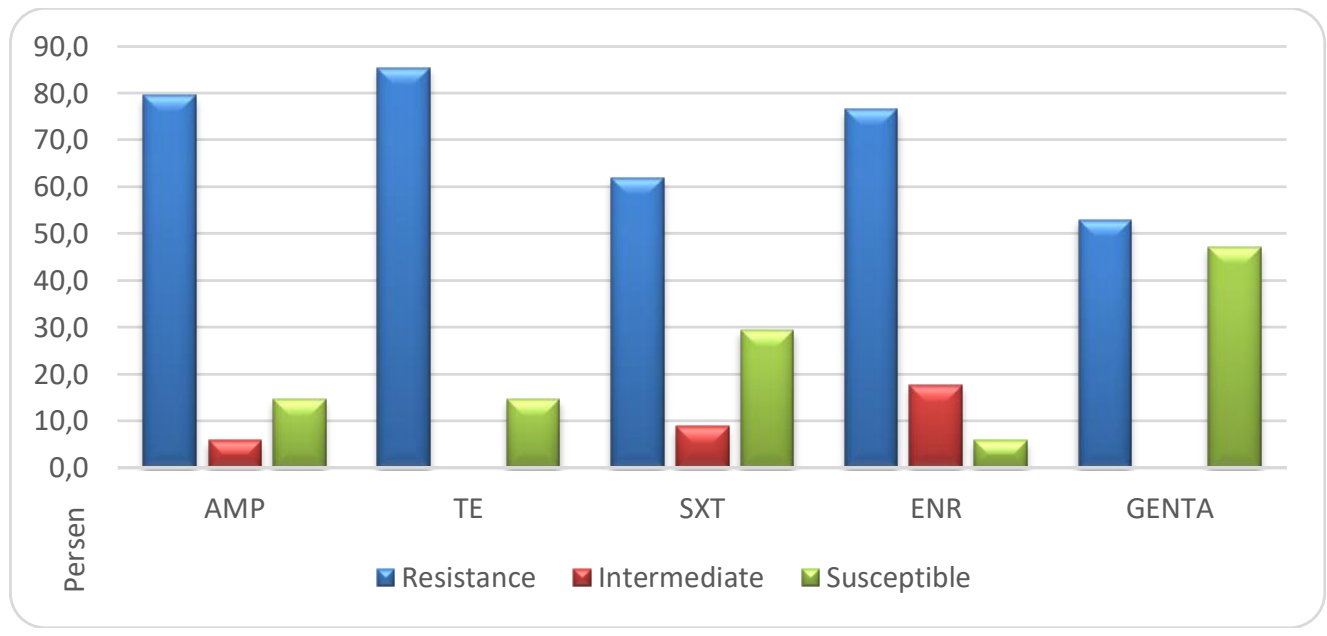

Figure 1. Antibiotic resistance, Ampicillin (AMP), Tetracycline (TE), SulfamethoxazoleTrimethoprim (SXT), Enrofloxacin (ENR) and Gentamicin (GENTA). 
Antibiotic resistance in a row from the largest percentage was Tetracycline (85.3\%), Ampicillin (79.4\%), Enrofloxacin (76.5\%), Sulfamethoxazole-Trimethoprim (61.8\%) and Gentamicin $(52.9 \%)$. While the number of antibiotics that are resistant from each sample is presented in the figure below.

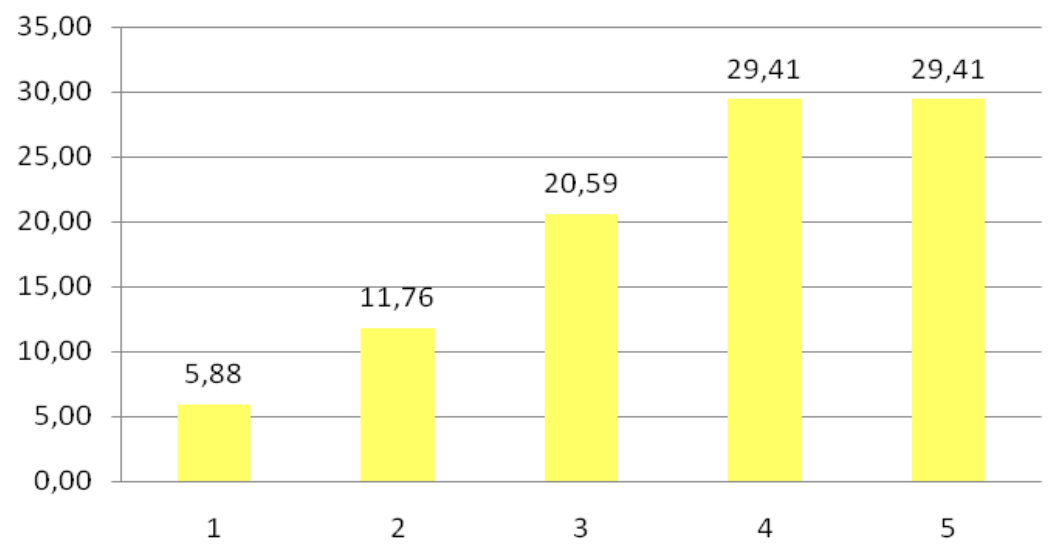

Figure 2. Description of resistance based on the number of resistant antibiotics.

Resistance to only one antibiotic received the lowest percentage of $5.88 \%$ while $91.18 \%$ of the other samples had minimal resistance to two types of antibiotics with the largest percentage $(29.41 \%)$ being resistant to four and all antibiotics being tested. More than $50 \%$ of the samples were resistant to all the antibiotics tested.

\section{Discussion and Conclusion}

Tetracycline and sulfa resistance occur because of the massive use of this antibiotic. In the period before 2018 where the use of Antibiotic Growth Promoter (ACP) has not been banned, tetracycline is an antibiotic that is generally added to feeds other than penicillin, macrolides, lincomycin, and virginiamycin (Angulo et al., 2004). AGP is an antibiotic with a sub-therapeutic dose that is expected to inhibit the growth of "bad" bacteria in the digestive tract so that animal growth can be increased. Research by the Veterinary Research Institute (1990 and 1991) states that most of the tested feed samples contain this antibiotic residue. Research conducted by (Bahri et al, 2005) states that $71.43 \%$ of feed mills in Bogor, Cianjur, Tangerang, Bekasi, and Sukabumi District add tetracycline and sulfonamide antibiotics in chicken feed.

Aside from being an additional feed, tetracycline is the most common antibiotic heard among farmers, so its use is relatively high. According to (Darsono, 1996) study of 30 chicken liver samples $83.3 \%$ positive for tetracycline residues, 93 chicken samples $70 \%$ positive oxytetracycline residues (Murdiati et al., 1998), 73 chicken samples $4.1 \%$ positive tetracycline residues (Werdiningsih et al., 2013), and 24 meat and chicken liver samples $4.17 \%$ positive tetracycline residue (Marliana et al., 2015).

The discovery of residues, both in muscles and organs, indicates improper use of antibiotics, especially drug downtime. The use of antibiotics that are not following the rules will eventually lead to resistance, both occur in bacteria found in individual animals, can also pollute the environment and spread to other regions through the spread of resistant bacteria. About $30.08 \%$ of small-scale broiler breeders do not have veterinarians; drugs are obtained directly from distributors or importers so that the use of drugs tends to not follow the correct rules (Kusumaningsih et al., 1996). 
The mechanism that is more or less the same occurs in other antibiotic resistance, the use of which is less concerned with usage and usage instructions are only based on past experiences. Fluoroquinolone was originally a promising antibiotic. Broad-spectrum and effective in treating bacterial diseases. Because it is known as the most effective antibiotic, so its use has increased sharply. Not long after being used as a drug in broiler chickens, enrofloxacin resistance began to appear. Ampicillin resistance occurs because ampicillin is a $\beta$-lactam class antibiotic, contradicting $\mathrm{E}$. coli which is a bacterium that has the enzyme $\beta$-lactamase. The resistance of $\beta$-lactam antibiotics easily spreads to other bacteria in the environment, because the gene encoding this enzyme is in plasmids (Peterson \& Bonomo, 2005).

Resistance to at least 3 types of antibiotics or multidrug resistance (MDR) has a large percentage, $79.41 \%$. With the largest percentage of $29.41 \%$ in resistance to 4 and 5 types of antibiotics. This is very worrying because broilers are generally susceptible to disease. Continuous and prolonged use of antibiotics can lead to antibiotic resistance, resistance may occur not only to the types of antibiotics given but to other types of antibiotics due to changes and transfer of bacterial genes (Marshal \& Levy, 2011). Resistant bacteria can also continue to exist in the enclosure environment if the cage disinfection process is not thorough and the cage is empty relatively quickly. These resistant bacteria will be able to exchange their resistance abilities with each other.

\section{Acknowledgment}

The author would like to thank the Maros Veterinary Center for giving permission to continue the education at the Hasanuddin University Postgraduate Program.

\section{Refferences}

Angulo, F., Nunneru, J., and Blair, H. 2004. Antimicrobial resistance in zzonotic enteric pathogens. Rev.SCi.Tech.Off.Int.Epiz, 23(2), 485-496.

Bahri, S., Masbulan, E., and Kusumaningsih, A. 2005. Proses Praproduksi sebagai faktor penting dalam menghasilkan produk ternak yang aman untuk manusia. Jurnal Litbang Pertanian, 24(1), 27-36.

Darsono. 1996. Deteksi Residu Oksitetrasiklin dan Gambaran Patologi Anatomi Hati dan Ginjal Ayam Kampung dan AYam Broiler yang Dijual di Lima Pasar Kotamadya Surabaya. Media Kedokteran Hewan, 12(3), 178-182.

Kusumaningsih, A., Murdiati, T., and Bahri, S. 1996. Jalur Pemasaran Obat Hewan pada Peternakan Ayam Burat di Beberapa Lokasi di Jawa Barat dan DKI Jaya. Hemera Zoa, 79(1-2), 72-80.

Marliana, N., Zubaidah, E., \& Sutrisno, A. 2015. Pengaruh Pemberian Antibiotika saat Budidaya terhadap Keberadaan Residu pada Daging dan hati Ayam Pedaging dari Peternakan Rakyat. Jurnal Ilmu-IImu Peternakan, 25(2).

Marshal, B., and Levy, S. 2011. Food Animals and Antimicrobilas: Impacts on Human Health. Clinical Microbology Review, 25(4), 718-733.

Murdiati, T., Indaningsih, and Bahri, S. 1998. Contamination at Animal Products by Pesticides and Antibiotics. ACIAR Proceedings, 115-121.

Peterson, D., and Bonomo, R. 2005. Extended-Spectrum B-Lactamases: a Clinical Update. Clinical Microbology Review, 18(4), 657-686.

Siswanto. 2014. Kajian Resistensi Antimikroba dan Situasinya pada Manusia di Indonesia. Seminar Nasional Dan Diskusi Interaktif Resistensi Antimikroba. Jakarta.

Werdiningsih, S., Patriana, U., Ariyani, N., Ambarwati, and Nugraha, E. 2013. Pengkajian Residu Tetrasiklin dalam paha, Hati dan telur Ayam pada Beberapa Provinsi di Indonesia. 
Buletin Pengujian Mutu Obat Hewan No 19 Tahun 2013. Balai Besar Pengujian Mutu dan Sertifikasi Obat Hewan. 